\title{
Sustainable Management at a University in Light of Tensions of Sustainability Theory
}

\author{
Gestão Sustentável em uma Universidade à Luz da Teoria das Tensões da \\ Sustentabilidade
}

Simone Sehnem $^{\mathbf{1 , 2}}$
(iD) https://orcid.org/0000-0002-2416-4881
Graciella Martignago

Universidade do Oeste de Santa Catarina, Departamento de Administração, Chapecó, SC, Brasil ${ }^{1}$ Universidade do Sul de Santa Catarina, Programa de Pós-Graduação em Administração, Florianópolis, SC, Brasil ${ }^{2}$ Fundação Getulio Vargas, Escola de Economia de São Paulo, São Paulo, SP, Brasil ${ }^{3}$ University of Stirling, Management Department, Stirling, Scotland, $\mathrm{UK}^{4}$ 


\title{
Resumo
}

Com base na teoria das tensões da gestão da sustentabilidade, este trabalho original tem como objetivo analisar as tensões que emergiram durante o processo de inserção da sustentabilidade nos principais processos de uma importante universidade brasileira. Onze entrevistas foram realizadas e analisadas através da categorização temática e uso do software Atlas-ti. Uma análise documental também foi realizada. Os resultados sugerem que: (a) houve predominância de tensões provenientes da dimensão organizacional; (b) a dimensão do desempenho está associada à pluralidade de resultados esperados pelas partes interessadas; (c) a assimetria existente entre a expectativa dos sujeitos e os resultados concretos visualizados na universidade Unisul contribuíram para o fato de que os pontos de tensão convergiram para a dimensão de desempenho; e desafiam os gerentes a encontrarem mecanismos para minimizar os dilemas e conflitos que emergem e alinharem as expectativas dos diferentes stakeholders da Unisul Sustentável.

Palavras-chave: sustentabilidade; tensões de sustentabilidade; urbanismo sustentável.

\begin{abstract}
Drawing on the theory of tensions of sustainability management, this original work aims at analysing tensions that emerged during the process of inserting sustainability at core processes of an important Brazilian university. Eleven interviews were conducted and analysed through the thematic categorisation and the Atlas ti software was used. A documental analysis was also carried out. The results suggested that: (a) there was a predominance of tensions originating from the organizational dimension; (b) the performance dimension was associated with the plurality of outcomes expected by stakeholders; (c) the existing asymmetry between the expectation of the subjects and the concrete results visualized in the Unisul University as contributed to the fact that the points of tension converged towards the performance dimension. And it challenged managers to find mechanisms to minimize the dilemmas and conflicts that emerged and to align the expectations of the different stakeholders of the Unisul Sustainable enterprise.
\end{abstract}

Keywords: sustainability; tensions of sustainability; sustainable urbanism.

JEL Codes: Q01, R00, M1. 


\section{Introduction}

This study aims to analyse the tensions of sustainability that emerged in the process of establishing a university campus in a sustainable neighbourhood. Part of the theory of tensions that T. Hahn, Pinkse, Preuss and Figge (2015) and Iizuka, Varela and Larroudé (2015) study is how organizations can deal with trouble spots and asymmetries between economic, social, and environmental dimensions of sustainability and develop management capabilities to pursue seemingly conflicting aspects. The motivations for conducting the research are associated with the fact that, as an object of study, it is an innovative case, rather unique in Brazil, a recent occurrence, and it presents a set of practices that align with the theme of sustainability, sustainable urbanism, and creative cities.

The university, situated in the Cidade Universitária Pedra Branca district, was chosen for the experiments identified and the practices already implemented, ones that residents, students, employees enjoy daily. These are practices that allow benchmarking and, above all, evidence of sucesses and errors in the process of raising the awareness and commitment of those involved. The main objective of the study was to analyse the tensions of sustainability emerging in the process and the strategies adopted to minimize them. There was also analysis of secondary elements, namely the sustainability practices highlighted by the interviewees and the historical path of the main events that have occurred and have been considered milestones in this case.

The gaps in the mapped literature indicate that the theme of tensions of sustainability has been studied very little so far (T. Hahn, Pinkse, Preuss, \& Figge, 2015). There is evidence that there are inconsistencies in the integration of environmental management activities and economic and environmental performance (Wagner, 2015), which may become a constraint on greater private sector investments in sustainable practices. So far, tensions of sustainability theory have not been applied to any study on sustainable management in Higher Education.

The contribution of this study isthe dissemination of valuable successful experience and the generation of an extension of the theory of T. Hahn et al. (2015). Deficiencies, weaknesses, and tensions were mapped in the process of establishing the sustainable campus. But the case also allows for acquisition of unique organisational and managerial learning, experienced in a region that does not have a culture of sustainability and needs to deal with traditional assumptions, values that are barely aligned with the principles of sustainability, and emerging strategies to circumvent conflicts and contribute to the success of the enterprise. Among the emerging tensions, it was possible to find efficient alternatives in the 18-year history of the venture and devise a strategic plan for the next 20 years, in order to consolidate sustainable practices idealised for Cidade Universitária Pedra Branca and the University of Southern Santa Catarina (Universidade do Sul de Santa Catarina [Unisul]). The choice of case is associated with a focus on the recent achievements of postgraduate courses, especially investments and visibility in master's and doctoral courses in health, education, linguistics, and administration. This allowed them to be environments for training athletes from different countries during the Olympics, because it has a modern, efficient, and welcoming structure.

\section{Tensions of Sustainability}

Sustainability in its genesis provides for an integrated and articulated vision among the economic, social, and environmental dimensions. However, the integrative view assumes that companies need to accept tensions in corporate sustainability. Different aspects of sustainability seem to contradict simultaneously. Corporate tensions of sustainability occur among different levels in the processes of change and within a spatial context (T. Hahn, Figge, Pinkse, \& Preuss, 2010).

Sustainability requires companies to interdependently address economic, environmental, and social concerns at different levels (Elkington, 1997). At the same time, often in instrumental logic, 
economic concerns are held above other concerns. Instrumental logic focuses on financial gains to the detriment of environmental and societal issues (Dentchev, 2004; Husted \& Salazar, 2006; R. Hahn, 2012; T. Hahn et al., 2015). Thus, situations where there is tension, and social aspects that cannot be aligned with financial aspects, results are discarded (R. Hahn, 2012). "This lack of consideration of tensions and conflicts contrasts with the complex, multifaceted nature of corporate sustainability" (T. Hahn et al., 2015, pp.1-2).

In addition, "sustainability refers to desirable outcomes at the global societal level, where firms are expected to improve the general well-being of society" (Schwartz \& Carroll, 2008, p. 168). Due to the emphasis on intergenerational equity, "sustainability emphasises the enduring character of the benefit that businesses are expected to provide to society" (T. Hahn, 2015, p. 3). Questions of sustainability are very complex and it should be recognized that these conflicting elements often involve different forms of decision making.

When it comes to sustainability, there are a number of stakeholders involved. Pressure can thus come from multiple directions and the financial market will not always reconcile these conflicts. Globally, corporate sustainability refers to interdependent social, economic, and environmental concerns at different levels. But companies need to address the three dimensions of the triple bottom line in a balanced simultaneous manner (T. Hahn et al., 2015). They are concerns often full of paradoxes and contradiction (Berger, Cunningham, \& Drumwright, 2007). In the world of corporate sustainability, there is a dearth of research done on tensions and conflicts. Only recently has an integrative vision emerged (T. Hahn et al., 2015). All these aspects need to be considered and solutions should be discussed and explored. Managers need an integrated view of social, economic, and environmental issues to recognize existing tensions.

Literature posits the conceptual terms strategic contradictions, tensions, paradoxes, and dilemmas as synonyms (Smith \& Lewis, 2011; T. Hahn et al., 2015). For this study we sought to focus on the typologies of stresses that are recurrently mentioned in the literature and which are described in Table 1.

Table 1

\section{Classification of Tensions of Sustainability}

\begin{tabular}{lll}
\hline Authors & Classification & Descriptor \\
\hline T. Hahn, & 1) Societal level & 1) Trade-offs between different economic, environmental and \\
Figge, Pinkse & 2) Industry level & social results at the societal level; \\
and Preuss & 3) Organizational Level & 2) Trade-offs between different economic, environmental and \\
$(\mathbf{2 0 1 0 )}$ & social results at the industry level; \\
& 4) Individual level & 3) Trade-offs between results of different economic, \\
& environmental and social organizations; \\
& 4) Trade-offs between individual interests and preferences of \\
& different actors in terms of economic, environmental and \\
& social outcomes
\end{tabular}

Csutora (2011) 1) Private value of shared value

2) Reach and depth

3) Management and measurement
1) suggests that improved sustainability efforts may be accompanied by a deterioration of sustainability performance.

2) proposes an existing trade-off between the scope and depth of sustainability agendas. The more we expand the list of items, the less we can capture the most important issues.

3) Researchers are increasingly aware of hidden pitfalls in policy performance and reach-depth paradoxes. Recently, new concepts have been developed to measure corporate sustainability positions or, at least, changes in these positions. More recent models are more focused on measuring performance than on policy measurement and address well-defined and substantial problems. 
Table 1 (continued)

\begin{tabular}{|c|c|c|}
\hline Authors & Classification & Descriptor \\
\hline $\begin{array}{l}\text { Smith and } \\
\text { Lewis (2011) }\end{array}$ & $\begin{array}{l}\text { 1) Ownership } \\
\text { 2) Performance } \\
\text { 3) Organization } \\
\text { 4) Learning }\end{array}$ & $\begin{array}{l}\text { 1) It suggests how organizational actors strive for self- } \\
\text { expression and group affiliation; } \\
\text { 2) Need to satisfy multiple stakeholders in the operations of the } \\
\text { organization and result in competing strategies and goals; } \\
\text { 3) It arises as complex organizational systems that create } \\
\text { competing projects; Structures, processes and practices to } \\
\text { achieve the desired results; } \\
\text { 4) It provokes processes of innovation and transformation that } \\
\text { reveal tensions between old and new practices. }\end{array}$ \\
\hline $\begin{array}{l}\text { T. Hahn, } \\
\text { Preuss, Pinkse, } \\
\text { and Figge } \\
(\mathbf{2 0 1 4 )}\end{array}$ & $\begin{array}{l}\text { 1) Personnel versus } \\
\text { Sustainability agendas } \\
\text { Organizational } \\
\text { 2) Short-Term Corporate } \\
\text { versus long-term } \\
\text { orientation } \\
\text { 3) Isomorphism versus } \\
\text { structural and } \\
\text { technological change } \\
\text { 4) Efficiency versus } \\
\text { resilience of } \\
\text { socioeconomic systems }\end{array}$ & $\begin{array}{l}\text { 1) The tension refers to processes of change in regard to } \\
\text { approach different economic, environmental and social } \\
\text { aspects and is situated between the Individual and } \\
\text { organizational levels. } \\
\text { 2) Guidance for environment, protection and social equity. The } \\
\text { tension refers to the different temporal Economic, } \\
\text { Environmental and social aspects and is situated within the } \\
\text { context of the temporal dimension; } \\
\text { 3) Tension acts between environmental and social aspects in } \\
\text { processes of change and operates between Organization and } \\
\text { Systemic levels; } \\
\text { 4) That is, its capacity to absorb shocks to tension refers to } \\
\text { conflicting processes between the } \\
\text { Organization and the systemic level }\end{array}$ \\
\hline
\end{tabular}

\begin{tabular}{ll}
\hline Iizuka et al. & 1) Performance \\
(2015) & 2) Organizational \\
& 3) Ownership \\
& 4) Learning
\end{tabular}

1) Related to performance: goals, metrics, stakeholder meeting and expectations.

2) Related to organizations: dynamic divergence due to different structure, culture, practices and processes.

3) Related to the feeling of belonging: divergent identities between groups, subgroups and the organization.

4) Related to learning: Timelines are different in the processes of change, growth, and scaling.

\begin{tabular}{ll}
\hline Haffar and & 1) Private Value-Shared \\
Searcy (2017) & Value Tension \\
& 2) Scope-Depth Tension \\
& 3) Measurement \\
& management tension
\end{tabular}

1) Social / environmental performance vs Financial Performance or Environmental Performance vs Social Performance;

2) Approach to implementation of performance objectives; Management and measurement approach and approach to conflict and performance areas;

3) Management approach (centralization versus decentralization) and measurement approach (relative versus absolute)

Note. Source: by authors.

International studies point to advances in the analysis of sustainability in the context of universities, though they are associated with the teaching of sustainability in institutions of higher education. In this sense, Adams, Martin and Boom (2018) proposed a conceptual framework for designing interventions, measuring and monitoring the construction and incorporation of a university culture of sustainability at a university in the United Kingdom. The authors emphasize that a sustainable university requires individuals who behave in a sustainable way: with autonomy, self-regulation, and responsibility. It is an environment where the behaviors expressed by the university are considered by all relevant stakeholders, with desirable quality, and are promoted as such. 
Aleixo, Leal and Azeteiro (2018) investigated how the main stakeholders (leaders, teachers, employees, students, and external stakeholders) of Portuguese Public Institutions of Higher Education perceive concepts of sustainability and sustainable higher education institutions, the role of higher education for sustainable development, and the barriers, challenges, and obstacles in the implementation of sustainable initiatives in Portuguese Public Institutions of Higher Education. The results show that some respondents view sustainability from an integrative perspective, covering the three pillars of sustainability (environmental, social, economic). Therefore, these findings do not confirm a holistic view of sustainability. The integration of sustainability in Higher Education Institutions (HEIs) is not so well understood. Most of the interviewees do not know the term Sustainable Higher Education Institutions (SHEI) and even classify the Portuguese HEIs, far from being considered as examples of the concept. The perception that there is no SHEI in Portugal is evidence similar to the results of other countries. The interviewees related the concept of SHEI to the lifetime of an institution, that is, if the institution has a long life, it is sustainable.

Bizerril, Rosa, Carvalho, and Pedrosa (2018) developed a systematic review on sustainability in higher education institutions in Portuguese-speaking countries. They mapped two potential contributions from these countries in the context of sustainable universities. The first is the link between IESs and society based on the tradition of an extension as one of the missions of HEIs, especially the Brazilian ones, evidence also mapped by Nogueira (2013). Second, the literature of Portuguese-speaking countries can provide experiences of technology transfer between universities and the private sector, especially the Portuguese case, as evidenced by Marques, Caraça, and Diz (2010). Another contribution that finds support in the work of Portuguese-speaking authors is the defense of democratic management and participation in decision-making processes that promote the emancipation of community members, which also includes school and university governance. Democracy is one of the main elements of universities in the 21 st century. This demand also includes social responsibility and the production of transdisciplinary and contextual knowledge, based on dialogue with other non-scientific knowledge.

On the other hand, Lozano (2011) emphasizes that developed countries value environmental aspects of sustainability more than social ones, a fact that has been justified by a supposedly easier measurement, evaluation, and analysis of environmental variables. In contrast to this study, Segalàs et al. (2012) have shown that, despite the fact that specialists, ie teachers and researchers in sustainable development education considered institutional and social aspects to be the most relevant to sustainability. A sample of 500 European engineering students has given more importance to technological and environmental development aspects, suggesting that the courses should emphasize the complexity of sustainability and revise their teaching strategies.

Hermes and Romanoczy (2018) argue that sustainability in managerial education is usually approached from a technical perspective. For this reason, they decided to elaborate a mental model contemplating emotional aspects oriented at sustainability. In this paper, authors based their work on a conceptual model to develop a sustainability mentality, and provide an example of how this was applied in the design of an undergraduate course in Multinational Business Management, Oulu Business School, University of Oulu, in Finland. Approaching knowledge, thinking systems, emotional aspects, tacit paradigms, and values adhered to, the students were taken on a journey of discovery that fomented deeper learning. The students were also moved out of their comfort zone and invited to occupy different perspectives than those that came naturally to them. The technique of taking students out of their comfort zone was considered useful in entering the learning zone of responsible management. This experience, therefore, was an alert to increase self-awareness, introspection, and the practice of tolerance and acceptance from different perspectives. The authors suggested that thinking and eco-literacy systems, when connected with emotions and personal values, can create a powerful transformation of worldview, leading to more thoughtful and compassionate behavior to the benefit of all. As such, developing this lens not only contributes to engaging in leadership behavior in sustainability, but also shape a better world.

Chuvieco, Burgui-Burgui, Silva, Hussein, and Alkaabi (2018) analyzed the environmental habits of university students from three countries: Spain, Brazil, and the United Arab Emirates (UAE). They tested three hypotheses: first, sustainability indicators will be higher for students of environmental 
degrees than for those of other disciplines, since the former should have a greater interest in environmental issues. The second hypothesis was that the habits of sustainability of students in environmental courses are greater for those in higher education courses than those in lower level courses, as they would be better informed about ecological problems and the importance of acting. The final hypothesis was that practices in sustainability will be greater for students with greater environmental concern. Other potential drivers of sustainability habits, such as gender and country of origin were also analyzed. The study was based on questionnaire results from a sample of 1011 students from three universities, one in each country. The results showed that the field of study and self-perceived environmental impairment were significantly associated with students' sustainability habits in two of the three indicators, while the years of study for environmental students was not considered significant in any of them. None of the three explanatory factors, the field of study, years of study or environmental concern were significantly associated with students' consumer self-consideration. Differences in country of origin were statistically insignificant, while differences between the sexes showed higher sustainability values for women in 38 of the 3 indicators in Brazil and Spain, but were not significant for the students of the Emirates. The irrelevant influence of the years of study for students of subjects related to the environment is an interesting debate about whether current environmental college education should not only impact knowledge, but also the students' mentality on sustainable and practical behavior.

Vieira et al. (2018) developed a study whose objective was to identify the barriers and motivations that influence the adoption of sustainable practices in higher education institutions (HEIs). A multiple case study was developed. This approach was used to analyze the influence of the barriers and motivations identified in the literature on two Brazilian HEIs. Five propositions were identified and discussed: governmental directives coercively promote the adoption of EMS practices in HEIs; stakeholders encourage the adoption of EMS practices in HEIs; the combination of top-down and participatory approaches is essential to maintain EMS practices in HEIs; the adoption of EMS practices in HEIs tends to face the challenges of several barriers; the adoption of EMS practices in HEIs tends to be motivated by a variety of factors. The conclusions show that the success of the adoption of the EMS showed a relationship between the barriers and motivations found in each HEI. Bureaucracy emerged as an additional significant barrier, capable of explaining some of the differences observed between IES Alpha and Beta. It appears to be responsible for the observed differences in the environmental performance of the Alpha and Beta institutions.

Zutshi and Creed (2018) described communications from Australian university websites on sustainability initiatives, especially related to the implimentatiom of the Talloires Declaration. This is publicly available information (time period 2014 and 2015, respectively) in the context of development education (ESD) in society and the transaction model in communication theory. It is found that some of the signatory universities in Australia have put into action some of the ten Talloires and this was divulged in their public communications, but each point was not emphasized with equal priority. The variation may be due to diverging underlying objectives or to create a strategic positioning tool to signal the university as an environmental advocate within a broader society. Focusing on secondary data from websites of signatory universities in Australia, the article provides a study of Talloires' higher education significance. This helps in the initial understanding of signaling theory in the public communication transactions that promote Talloires' action and implementation. The results encourage further studies of communication issues related to universities in other countries. The document also deepens local understanding and global perceptions of sustainability and contributes to the body of comparative sustainability literature in higher education as a component of strategic ESD management development.

Soini, Jurgilevich, Pietikäinen, and Korhonen-Kurki (2018) seek to understand the various ways in which universities are responding to the societal challenge of sustainability by analyzing a sample of 44 sustainability centers around the world to increase understanding of the characteristics and roles of these centers in contributing to sustainability. In addition, the study identifies four types of centers that differ in their objectives, objects, scope, and scale of research, knowledge production activities and dissemination. The typology of centers can be applied, for example, when new centers are established or when centers identify or redefine their profiles. The authors also suggest research on sustainability 
centers, given their central role as research nodes in sustainability, education, and co-creation in the transformation of sustainability.

\section{Methodology}

This study describes the case of Cidade Universitária Pedra Branca, where the Unisul Campus of Greater Florianópolis is located. The criterion for selecting the case is associated with the fact that Unisul is the first university in southern Brazil to establish a campus inserted in a sustainable neighbourhood with intentional interaction with nature and appreciation of community health and well-being. The campuses an integral part of the Cidade Universitária Pedra Branca district - built and developed in the year 1980 based on the concept of sustainable urbanism. The location of the campus favours access to the site with bus routes to the university, and offers a variety offlats for rent, as well as restaurants, supermarkets, pizzerias, snack bars, bakeries and chemists (UNISUL, n.d.).The choice of a Brazilian university is associated with the fact that the decentralisation of university education in the country has a recent trajectory compared that in Europe and the United States. Thus, there are opportunities to plan the campus infrastructure by conforming to contemporary architecture and sustainability premises.

The research design can be seen in Table 2 .

Table 2

\section{Research Design}

\begin{tabular}{ll}
\hline Method & Classification of this Study \\
\hline Research approach & Qualitative \\
\hline Search strategy & Descriptive \\
\hline Research method & Case study \\
\hline Data collection technique & Interview script \\
& Documents \\
& Website \\
\hline Subjects involved in research & 2 idealizers of the University City \\
& 2 Unisul administrators \\
& 2 residents of the University City \\
& 5 Unisul students (Listen to the user's point of view) \\
\hline Data tabulation technique & Full transcript of the respondents' speeches \\
\hline Data analysis technique & using the Atlas-ti software \\
& Categorical analysis and \\
\hline
\end{tabular}

Note. Source: by authors.

The subjects were chosen based on the criterion, key informants, that is, those knowledgeable about the implementation process, who experience the day-to-day life of the campus and the neighbourhood, and have a significant amount of information about the object under analysis. The selected key informants were the idealizers of the venture since they were the ones who conceived the strategy to make feasible the construction and implantation of the Cidade Universitária Pedra Branca. The two managers were selected because they operate/manage the day-to-day of the venture, experiencing their tensions, their potentialities and their challenges of consolidation of the Cidade Universitária Pedra Branca. The two residents were selected because they were pioneers, that is, the first residents who came to reside in the enterprise. Therefore, they know the routines of the University City 
and have extensive knowledge about the day-to-day life of the Campus. The 5 Unisul students were selected because they are university leaders and who live and enjoy the potential of the University Campus. They attend courses that are aligned with a formation linked to sustainable development, which develops skills and competencies to build a fairer, more humanized society that is able to respect natural resources and to ensure the adoption of sustainable practices in the day of organizations and in the life of every citizen. Therefore, the study contemplated different stakeholders, from the developer of the enterprise, the manager, the resident, and the usufruct - student, who spends at least 4 hours per day in the venture.

The justification for these methodological choices is associated with the fact that it is a focal organisation that implements innovative practices and co-operates with other civil and non-civil organisations. In addition, it develops inter-organisational skills within the sustainability theme. In order to have a profound understanding of this organisation, the case study has proven to be a pertinent research strategy, and the qualitative approach allows an in-depth insight into the organisational meanderings associated with the theme in question.

The protocol of the interview script was developed in the light of the literature, and the questions contemplated were about: how the university city arose and how its history occurred, the difficulties in the implementation of sustainable practices, the facilitators to engage with sustainability, the motivations to invest in sustainability, the sustainable practices adopted, engagement of materials suppliers, residents and students with sustainability, and whether the neighbourhood exerts some leadership in the sustainability rankings, whether there are indicators of the personal values of campus administrators, structures that encourage adoption of sustainable practices in the university city, and the lessons learned in the process of establishing the university district.

To preserve the anonymity of the interviewees, the following codenames were adopted, according to Table 3.

Table 3

Codenames of Respondents

\begin{tabular}{ll}
\hline Interviewee Profile & Codename Adopted in Article \\
\hline $\mathbf{2}$ project creators & Ideal 1 \\
& Ideal 2 \\
\hline $\mathbf{2}$ current project leaders & Administrator1 \\
& Administrator 2 \\
\hline $\mathbf{2}$ project residents & Dweller 1 \\
\hline $\mathbf{5}$ students- (Listen to the user's point of view) & Dweller 2 \\
& Student 1 \\
& Student 2 \\
& Student 3 \\
& Student 4 \\
& Student 5 \\
\hline
\end{tabular}

Note. Source: by authors.

The interviews were conducted face to face, recorded and transcribed in full. They rendered a total of 68 pages transcribed in full. Respondents' permission was requested to record the conversations. The anonymity of the respondents was maintained and the codename was assigned to each of them, as described in Table 2. The interview period occurred from January to May 2017 and was conducted by the authors of this article. The analysis of the data followed the thematic categorisation, following the precepts of Bardin (2011). Figure 1 shows the steps that were followed to elaborate the case described in this study. 


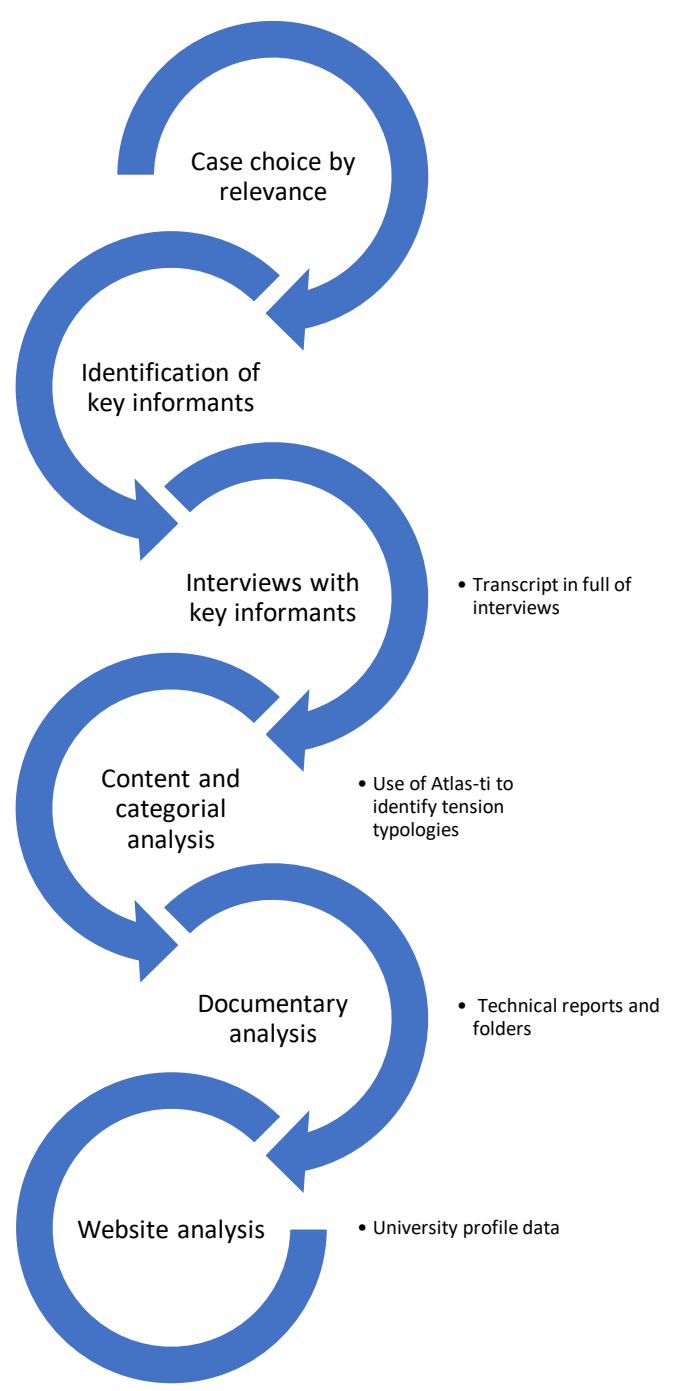

Figure 1. Stages of the Research

The research period was from January to May 2017. It resulted in 48 pages of full transcript of interviews conducted and 114 pages of documents. These data were compared with the theory of tensions of sustainability.

\section{Results and Analysis}

Unisul is a university that has 24,201 students, 119 undergraduate courses, 69 latosensu graduate courses, 5 master's degree courses and 2 doctoral programmes. It has a decentralised campus structure. The research described in this article was developed at the campus in Greater Florianópolis, located in the city of Palhoça, in the Cidade Universitária Pedra Branca neighbourhood, Santa Catarina State, Brazil. This campus has 4,249 students, 24 undergraduate courses, 3 lato sensu graduate courses, 3 master's degree courses and 2 doctoral courses.

The site of the Pedra Branca enterprise was originally a farm bought by a family of entrepreneurs around 1980, with approximately 250 hectares, and used for the purposes of leisure and business (livestock). 
The town of Palhoça - SC was growing and occupying the surrounding area of the farm, and the owners' weekend leisure was becoming insecure, as the land was becoming occupied by people of low income, involved in a lot of illegal clandestine annexation, in circumstances of relative absence of the State. There was adequate modern infrastructure on the farm for the owners and their friends, but the high level of poverty in the surrounding area made the place insecure, contributing to the family no longer using it. However, the farm maintained its livestock activity, and this was taken care of by the Portobello Group agricultural division to ensure that something was done with the remaining land.

Difficult access to the farm made a property venture impossible. There was difficulty in acquiring a neighbouring farm, which could allow the implementation of adequate access. Through a family member who worked at Unisul in the 90s, Ideal 1 have heard that Unisul, which had its headquarters in Tubarão, planned to set up a campus in Greater Florianópolis. The city hall was to make it viable, because it was a community university, and there was a desire for it to be linked to the municipality. Unisul was not gaining ground and the owners donated 15 hectares of the farm to make the establishment of the Universidade do Sul de Santa Catarina [University of Southern Santa Catarina] in Greater Florianópolis feasible, thus having its head office in the city of Palhoça, in Santa Catarina State, Brazil. Today, Palhoça has urbanised and the Cidade Universitária Pedra Branca has acted as an accelerator for the urbanisation of the municipality.

Ideal 1 emphasises that the purpose of the donation was associated to the transformation of the farm into a university city due to the morphing from a rural to an urban area, and the consequent appreciation in value of the area above the market level of the time. The requested counterpart, in order to make the donation feasible, was for the university administrators to apply to the city hall for expropriation of a piece of land (70 to 100 square metres) that was preventing access to the farm, which would make it possible to build a road. This negotiation made the farm an appropriate space to build an innovative differentiated enterprise, bringing concepts that, until then, had been little known in Brazil.

Unisul set up a campus that served 3,000 students at the time (1998), and Portobello set up a team of designers that included the architect, Hector Vigliecca from São Paulo and the architect, Silvia Lenzi from Florianópolis, with the aim of creating a sustainable urbanism project for the university city, Pedra Branca (Ideal 1).

There was an understanding that the spatial distribution of Greater Florianópolis could bring a great opportunity to the town of Palhoça. The Florianópolis island accounts for around 470 thousand inhabitants, which corresponds to a third of the total metropolitan population. The other two thirds live on the mainland (composed of the municipalities of Kobrasol, Biguaçu, São José and Palhoça), for several reasons: the town of Kobrasol does not have a central square, only a main street; the town of Biguaçu has never had a centre. The town of Palhoça had no attraction, nor did the town of San José. In addition, the cost of living on the island was very high from the urban point of view, due to environmental restrictions. The town of Kobrasol was a residential subdivision for with medium and lower middle class people. And there was the understanding that the town of Palhoça should create centrality for the mainland area, that is, to be a point of reference. But this point of reference should be a town and not just a subdivision. Townwas understood as a space with facilities that have more than one function, and settlement when it has only houses (Ideal 1). Therefore, Ideal 2 states that a real townisa compact, dense place where people can live, work and have fun.

At the end of the 90s, the first stages of the Cidade Universitária Pedra Branca project were launched. There was resistance from the people to acquire land there, in the middle of the cattle ranch, in a space so far away, and also, internal pressure from the shareholders. But, despite the difficulties, the first project phases were a success. They were predominantly familiar architectural designs.

Then, for the launch of the second stage of the project, the consulting company, DPZ, 8 architecture offices and a group of engineers were hired to make a new sustainable urbanism proposal feasible. The urban planners' emphasis was on the neighbourhood. The proposal was in line with the concepts of eco quartier, eco neighbourhood. To transform the neighbourhood into a sustainable space, the work proposal was adopted with the concept they call charrete [cart]. Thiscart is in fact a traditional 
term for a workshop, one where the team dedicates itself, full time, exclusively toa particular project. All the staff were trained to work with the concept of the cart, and courses were run, etc. A deadline was established to start operating full time with all the agents involved in the process, including the city hall, environmental agencies, etc, and there was a deadline for completion. Usually the cartwas operated for seven days. In the case of Pedra Branca, this lasted around 10 days.

"Four or five US architects came and joined our staff: energy personnel, environmentalists, a group of about 30 or 40 peoplewho ended up staying. They worked from 7 in the morning to 10 at night. In the main house, we set up a full scale office witha table on which everyone drew, everyone looked- a collective, a co-operative, and much conflict. So we learned to manage this conflict, and then we developed an ability to deal with it. And, at the end of 8 days, the Pedra Branca master plan was ready, which, until today, is followed, acting as a guide. Of course this is not rigid; it changes over time" (Ideal 1).

Pedra Branca's master plan was built on 10 concepts, as follows:

1. Balanced compact density: the number of inhabitants per hectare acts as an indicator. The traditional American density of the suburbanisation phenomenon, and that of settlements, which progressively occupy the land and exhaust the useful soil, which is serious, and demands transport, which, along with other public services, are free. Just a rich nation can bear this. Water, sewage, energy, communication, transport, health and safety have to be covered. Low density makes it difficult to provide public services, aggravates the sense of insecurity, demands individual transport, highlights Ideal 1. The density in Pedra Branca is 10,000 inhabitants in the 250 hectares, which will increase in the coming years due to the launch of new buildings.

2. Connectivity: from the neighbourhood to the surroundings - open neighbourhood without walls and fences, wi-fi in public spaces, mobility plan with cycle paths, and commercial competition;

3. Sustainability and high performance of the built environment: materials, projects, reduction of water consumption, energy, in the building itself and in the public environment: more efficient lighting, more efficient transport, water and sewage network.

4. Pedestrian priority: pavements were designed to be integrated with buildings, flats and gardens;

5. Mixed use: harmony between urban and residential space, that is, on the same street, on the same block, in the same building, store, office and dwelling. Mixed use prevents this segregation of functions and reduces the need for displacement. The whole thesis is about avoiding the use of the car.

6. Safe attractive public spaces. Meeting point for a diversity of people; urban landmarks; stages for cultural manifestation, stimulating contact with nature and with other people. "Combination of cafés, squares, shops, parks, restaurants, wide tree-lined pavements and gardens. Safe attractive environments that provide excitement, surprise and well-being for body and soul" (Cidade Criativa Pedra Branca, 2016, p.1).

7. Diversity of residents: absence of social segregation in the neighbourhood - need to have all social classes in the same environment. "We can not have allotment class A, B, etc. Without social mixing, the city is unsustainable from an environmental and human point of view," says Ideal 1.

8. Sense of community: socializing in the residents' association in Pedra Branca. The satisfaction of feeling integrated in a unique place, being recognised and recognising a good part of one's neighbours. A place that offers varied possibilities of encounter and experience (Cidade Criativa Pedra Branca, 2016).

9. Harmony between nature and urban amenities: presence of diversity and people sharing spaces, such as lifestyle, youth and urbanity, Pedra Branca walk.

Natural light, fresh clean air, wandering freely among buildings conveniently arranged among streets, parks, gardens and squares. Buildings that seek the best solar orientation and the 
prevailing winds. Balance between green areas and built-up areas. Richness of parks with native plants. Shading with trees along the pavements providing comfort and contemplation. Proximity between wildlife and urban life (Cidade Criativa Pedra Branca, 2016).

10. Ecosystem of innovation: use of practices of sustainable urbanism and creative economy. Unisul has the Institute of Support to Innovation, Science and Technology (Inaitec), located in Pedra Branca.

In addition, there is investment in refuse collection and recycling. There is use of the neighbourhood management model: the concept was incorporated by the residents' association. Sustainable buildings were built. In summary, to make viable all the existing infrastructure, the Pedra Branca timeline comprises the following significant events, described in Figure 2.

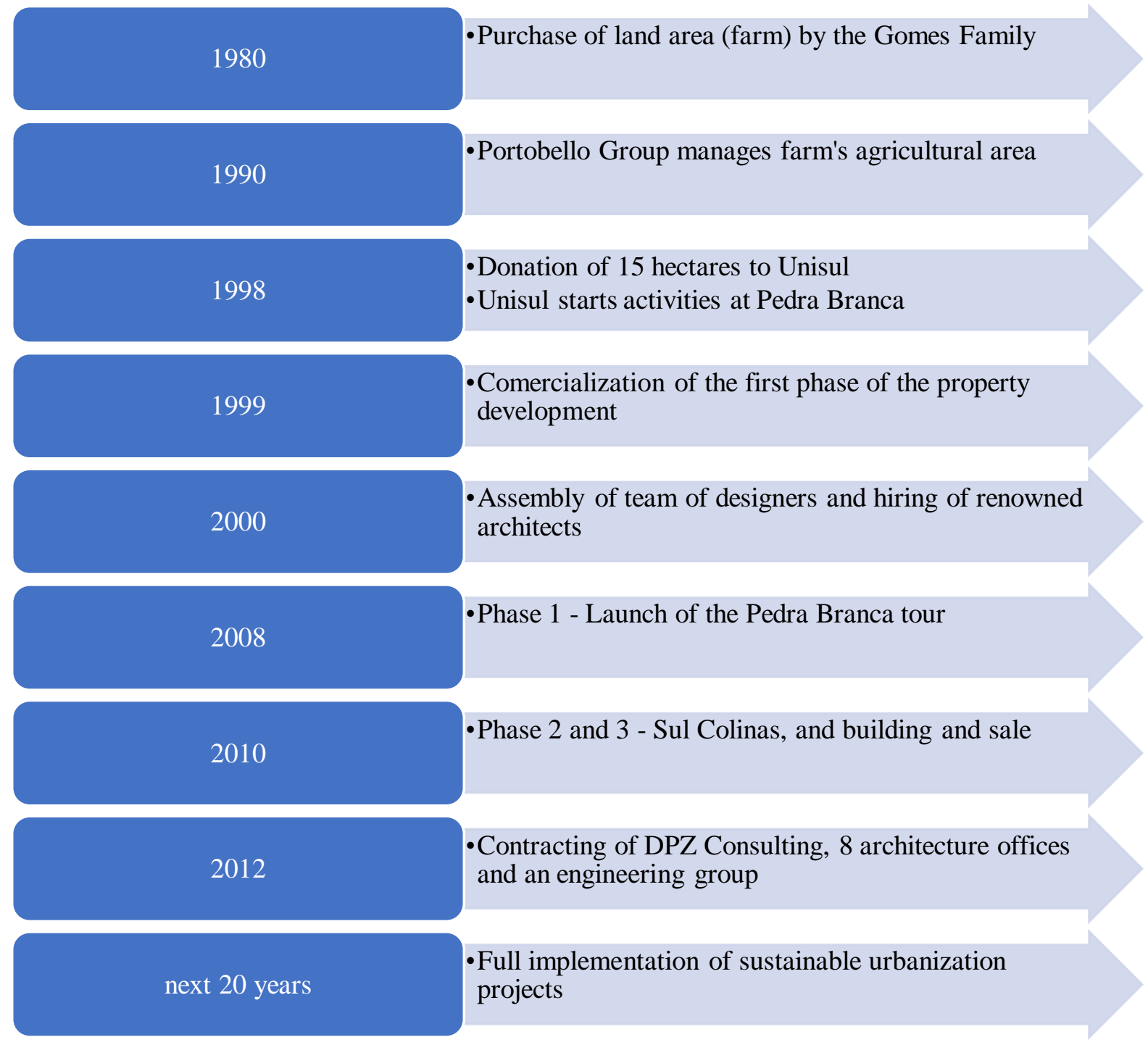

Figure 2. Events Representative of the Pedra Branca Implementation

Today, the university city Pedra Branca has 10,000 people living there, 7 thousand who work there and 6 thousand who study. The future prospect, with a horizon of the next 20 years, presents an estimate of having 40 thousand residents on the 250 hectares of Pedra Branca, 30 thousand workers and 10 thousand students. Pedra Branca's proposal presents several sustainable practices, as highlighted by the interviewees (see Table 4). 
Table 4

Sustainability Practices Adopted by Pedra Branca, and Limitations and Weaknesses still in Existence

\begin{tabular}{|c|c|c|}
\hline Interviewed & Sustainable Practices & Limitations and Frailties \\
\hline Ideal 1 & $\begin{array}{l}\text { Meets the Kyoto Protocol } \\
\text { Reduction of water and energy consumption } \\
\text { Reducing } \mathrm{CO}_{2} \text { emissions } \\
\text { Encouragement to walk, cycle and use public } \\
\text { transport } \\
\text { Establishment of small businesses to serve the city }\end{array}$ & $\begin{array}{l}\text { Advance in the parameterisationso as not } \\
\text { to remain only in the qualitative } \\
\text { discourse }\end{array}$ \\
\hline Ideal 2 & $\begin{array}{l}\text { Greenbuildings } \\
100 \% \text { treated sewage } \\
\text { Urbanism that would make it easier to leave the } \\
\text { car in the garage, live and work at home or } \\
\text { nextdoor. } \\
\text { Infrastructure with high performance and focused } \\
\text { on sustainability } \\
\text { Buildings that reduce their impact over time, i.e. } \\
\text { consume less energy, have a low maintenance } \\
\text { cost, capture rainwater for day-to-day use. } \\
\text { Use of LED lamps to reduce energy consumption, } \\
\text { including in public spaces. } \\
\text { More sustainable water heating within buildings } \\
\text { Green office with air conditioning and air } \\
\text { renovation, with modern machines. } \\
\text { Artesian wells within the neighbourhood } \\
\text { Only } 10 \% \text { of water loss from capture to } \\
\text { consumption (the country average is } 50 \% \text { loss) } \\
\text { Incentive to use bicycles. } \\
\text { - Now studying at Unisul Pedra Branca. You can } \\
\text { rent a nice flat here, have a pub, have a Japanese, } \\
\text { have a barbecue, have co-working. Events are } \\
\text { happening, creates a cooler environment } \\
\text { - Technologies that have generated a cost decrease }\end{array}$ & $\begin{array}{l}\text { Green office implied an increased cost } \\
\text { burden for the owner in buying more } \\
\text { sophisticated air conditioning than the } \\
\text { standard model. } \\
\text { Solve the problem of refuse inside the } \\
\text { neighbourhood, so you do not need more } \\
\text { than onelorry to transport it to the landfill } \\
\text { - Use the smartphone, applications and } \\
\text { the community's own participation in } \\
\text { the solutions } \\
\text { - Co-create a new, innovative bus stop } \\
\text { with GPS, etc. }\end{array}$ \\
\hline Adminstrator 1 & $\begin{array}{l}\text { - Green office, } \\
\text { - LEED Certification - leadership in energy and } \\
\text { environmental design } \\
\text { - Actions related to waste } \\
\text { - Use of special glass to promote luminosity } \\
\text { - Specific floor grout that does not contain } \\
\text { volatiles }\end{array}$ & \\
\hline
\end{tabular}




\section{Table 4 (continued)}

\begin{tabular}{|c|c|c|}
\hline Interviewed & Sustainable Practices & Limitations and Frailties \\
\hline Adminstrator 2 & $\begin{array}{l}\text { - Recycled refuse sites, waste separation } \\
\text { - Water reuse } \\
\text { - LEED Certification for Buildings } \\
\text { - Adopt a dog instead of buying } \\
\text { - Not all devices should stay on stand-by (unplug } \\
\text { to decrease electricity consumption) } \\
\text { - I do most of my shopping on foot } \\
\text { - Certification of buildings with the Bill Clinton } \\
\text { Foundation } \\
\text { - Use of led lamps } \\
\text { - There is sewage treatment } \\
\text { - We have security, well-being, comfort, mobility, } \\
\text { places to stroll, places to walk with the dog }\end{array}$ & $\begin{array}{l}\text { The residents' association should not } \\
\text { charge a monthly fee, but rather, } \\
\text { request responsibility; } \\
\text { - It's no use having a sustainable mega } \\
\text { city if people in the community throw } \\
\text { litter on the ground } \\
\text { - People lack awareness to do the basics } \\
\text { - It's no use bringing a great architect } \\
\text { with worldwide experience, if the } \\
\text { corner guy does not practice } \\
\text { sustainability } \\
\text { The concept is oriented to marketing } \\
\text { and not to sustainability, the university } \\
\text { and creativity }\end{array}$ \\
\hline Dweller 1 & $\begin{array}{l}\text { - Residents sorttheir refuse } \\
\text { - Isolated movements of rainwater reuse } \\
\text { - Within Unisul, the solar heating project } \\
\cdot \text { It has a bike rack and is empty } \\
\text { - Wooded streets, there are squares } \\
\text { - The sewage is treated }\end{array}$ & $\begin{array}{l}\text { There are no pavements in the streets } \\
\text { - There is no bike path } \\
\text { - There is no engagement } \\
\text { - No waste bins for separatiingrefuse. } \\
\text { - There is a project in partnership with } \\
\text { Eletrosul to change all the electrical } \\
\text { fittings at Unisul and install led bulbs } \\
\text { - Must have sustainability policies } \\
\text { There is no evidence of effective } \\
\text { integration with the local community }\end{array}$ \\
\hline Dweller 2 & $\begin{array}{l}\text { Waste, you need to separate, wash and take to a } \\
\text { collection point } \\
\text { - Partially use solar energy } \\
\text { - Lighting with photovoltaic cell on pavement } \\
\text { - Some buildings with water reuse } \\
\text { - There is sewage treatment } \\
\text { - The commercial rooms use air-conditioning - } \\
\text { green air model } \\
\text { - Pedra Branca works in line with the guidelines } \\
\text { of the Bill Clinton Foundation * } \\
\text {. "We have macaws, jackdaws, toucans on the } \\
\text { balconies of our residences; } \\
\text { - The supermarket Hippo has a vegetable garden }\end{array}$ & $\begin{array}{l}\text { Constantly missing power and burning } \\
\text { appliances Constant power failures, low } \\
\text { tension and surges that damage } \\
\text { electrical goods } \\
\text { - Residents do not make compost }\end{array}$ \\
\hline Student 1 & $\begin{array}{l}\text { There is less litter in the street (it's cleaner) } \\
\text { - Reuse of paper and cardboard boxes at Unisul } \\
\text { - Coloured boxes to put paper that can be reused } \\
\text { in Unisul } \\
\text { - Solar energy on the promenade (main street) }\end{array}$ & \\
\hline
\end{tabular}


Table 4 (continued)

\begin{tabular}{|c|c|c|}
\hline Interviewed & Sustainable Practices & Limitations and Frailties \\
\hline Student 2 & $\begin{array}{l}\text { Houses with solar panels } \\
\text { - Making paper blocks for sketching } \\
\text { - On the promenade there is solar energy (main } \\
\text { street) }\end{array}$ & $\begin{array}{l}\text { Unisul should institute a selective } \\
\text { collection policy }\end{array}$ \\
\hline Student 3 & $\begin{array}{l}\text { - Use both sides of paper and subsequent donation } \\
\text { to an indigenous tribe } \\
\text {. euse of glass } \\
\text { - Classes of students plant trees and put up small } \\
\text { signs. } \\
\text {. Unisul Solar Project in elementary school }\end{array}$ & $\begin{array}{l}\text { There is no selective collection within } \\
\text { Unisul } \\
\text { Deploy project with Install solar panels } \\
\text { in Unisul buildings }\end{array}$ \\
\hline Student 4 & $\begin{array}{l}\text { The structure of the new building (sustainable } \\
\text { architecture) } \\
\text { Collection of paper, in the colored boxes, where } \\
\text { we store the paper that can be reused } \\
\text { - The xerox companies also recycle } \\
\text { - Hitchhiking incentive } \\
\text { - People who live nearby come on foot }\end{array}$ & \\
\hline Student 5 & $\begin{array}{l}\cdot \text { Nature preservation practices } \\
\cdot \text { Separation of organic waste from recyclable } \\
\cdot \text { Existence of photovoltaic panels }\end{array}$ & \\
\hline
\end{tabular}

Note. ${ }^{*}$ Initiatives in the themes: climate change, economic development, girls and women, global health and health and wellbeing

It is noted in the interviewees' comments that there are several practices that are associated with sustainability. However, it is unanimous that they are practices developed in isolation. They lack an integrated system of management, communication and awareness to enable adherence to them. Furthermore, there is implementation of sustainable performance monitoring indicators. These findings diverge from those pointed out by Aleixo et al. (2018), whose study showed that there is a slow movement and few strategies for the implementation of sustainability in Portuguese HEIs, at least among the participants of this study. Even though different stakeholders (internal and external) are more aware of sustainability, there is no clear strategy on their promotion.

In addition, it was highlighted by Ideal 2 that Pedra Branca bears the Inmetro (Procel) seal, which certifies buildings as sustainable from the energy point of view. The Atrium and Green Office buildings have international sustainability certifications.

When we compare the sustainable practices cited by the interviewees, it is possible to perceive that there is a unanimous opinion about the adoption of clean energies, adoption of practices that reduce the ecological footprint of the human being, that are of simple adoption, and that contribute to the reduction of residues and that allow urban mobility in a more agile and less polluting way. It is clear that the message passed by the interviewees is associated with the optimization of the use of natural resources, minimization of environmental impacts and intelligent assets associated with the consolidation of a sustainable society. And this demands the formation of a level of consciousness, which is consistent with attitudes and behaviors towards sustainability. These aspects align with Adams et al. (2018), who in their study mentioned that the notion of organizational culture implies a set of shared goals and values shared by members of the organization that inspire and motivate consistent behaviors. Culture is made up of artifacts, values, and assumptions adopted, Adams et al. (2018) show that this reinforces the importance of accessing national and international best practices and networks, 
as well as examples of sustainability implementation in HEIs, as this could provide important clues about how Portuguese higher education institutions can respond to challenges related: competitiveness, funding, student enrollment, institutional partnerships and the quality and excellence of teaching and research (Aleixo, Leal, \& Azeteiro, 2018).

However, universities are a particular case, characterized by transient populations of students some of whom join freshmen and maybe due to previous life experiences, unfamiliar with the desired behaviors. Evidence from Adams et al. (2018) when they mentioned the case that students arrive at the University of Worcester (UW) without a general awareness of sustainability issues and therefore needed to be updated on the subject. And it corroborates with the findings of Aleixo et al. (2018) who showed in their study that all respondents believe that HEIs play a role in the search for a sustainable future. And finally, an organizational culture of sustainability develops over time due to actions applied in the visible layer and is probably manifested in different ways within subcultures (Aleixo et al., 2018). Above all, because HEIs have a university social responsibility (Aleixo et al., 2018).

\section{Mapping tensions of sustainability}

Emerging tensions of sustainability were mapped by thematic categorisation in the implementation of the sustainable city, Pedra Branca and the Unisul de Palhoça Campus. We have mapped 47 different codes, as described below:

Table 5

Perceptions of Tensions in the Simultaneous Management of Social, Environmental and Financial Performance

\begin{tabular}{lll}
\hline Mapped Tensions at Unisul* & $\begin{array}{l}\text { Alignment with Theoretical } \\
\text { Dimensions }\end{array}$ & Author Reference \\
\hline Inefficient communication $\{\mathbf{2 6 - 2}\}$ & Organizational Dimension & Iizuka et al. (2015) \\
\hline Few isolated practices $\{\mathbf{2 4 - 1}\}$ & Performance Dimension & $\begin{array}{l}\text { Iizuka et al. (2015); Smith and } \\
\text { Lewis (2011) }\end{array}$ \\
\hline Commitment $\{\mathbf{1 9 - 0}\}$ & $\begin{array}{l}\text { Dimension Ownership } \\
\text { and Individual level }\end{array}$ & $\begin{array}{l}\text { lizuka et al. (2015); T. Hahn et } \\
\text { al. (2010) }\end{array}$ \\
\hline $\begin{array}{l}\text { Lack of disclosure of sustainability } \\
\text { indicators }\{\text { 11-0\} }\end{array}$ & Societal level & T. Hahn et al. (2010) \\
\hline Lack of infrastructure $\{\mathbf{1 0 - 0}\}$ & Organizational Dimension & Iizuka et al. (2015) \\
\hline $\begin{array}{l}\text { Lack of understanding of the concept of } \\
\text { sustainable urbanism }\{\mathbf{9 - 0}\}\end{array}$ & Individual level & T. Hahn et al. (2010) \\
\hline Too much marketing $\{\mathbf{9 - 1}\}$ & Dimension Range and Depth & Csutora (2011) \\
\hline Absence of a policy for sustainability $\{\mathbf{8 - 4}\}$ & $\begin{array}{l}\text { Dimension Private value of } \\
\text { shared value }\end{array}$ & Csutora (2011) \\
\hline Waste of natural resources $\{\mathbf{8 - 1}\}$ & Performance Dimension & $\begin{array}{l}\text { Iizuka et al. (2015); Smith and } \\
\text { Lewis (2011). }\end{array}$ \\
\hline Difficulty of access $\{\mathbf{8 - 1}\}$ & Organizational Dimension & lizuka et al. (2015) \\
\hline Geographical location isolated $\{\mathbf{8 - 1}\}$ & Organizational Dimension & Iizuka et al. (2015) \\
\hline Lack of connectivity $\{\mathbf{7 - 1}\}$ & Dimension Ownership & Smith and Lewis (2011). \\
\hline Absence of selective collection $\{\mathbf{7 - 0}\}$ & Organizational Dimension & Iizuka et al. (2015) \\
\hline
\end{tabular}


Table 5 (continued)

\begin{tabular}{|c|c|c|}
\hline Mapped Tensions at Unisul* & $\begin{array}{l}\text { Alignment with Theoretical } \\
\text { Dimensions }\end{array}$ & Author Reference \\
\hline Collective coexistence $\{6-1\}$ & Learning Dimension & Smith and Lewis (2011). \\
\hline There is no engagement. $\{6-2\}$ & Dimension Ownership & Smith and Lewis (2011). \\
\hline Lack of security $\{5-0\}$ & Organizational Dimension & Iizuka et al. (2015) \\
\hline Many conflicts $\{5-3\}$ & Dimension Ownership & Smith and Lewis (2011). \\
\hline Affordable Sustainability $\{5-1\}$ & Societal level & T. Hahn et al. (2010) \\
\hline $\begin{array}{l}\text { Lack of knowledge of sustainable practices } \\
\{4-0\}\end{array}$ & Individual level & T. Hahn et al. (2010) \\
\hline Management of organic matter $\{4-0\}$ & Organizational Dimension & Iizuka et al. (2015) \\
\hline Difficulty establishing in the region $\{3-1\}$ & Organizational Dimension & Iizuka et al. (2015) \\
\hline Poor transport systems $\{3-1\}$ & Organizational Dimension & Iizuka et al. (2015) \\
\hline $\begin{array}{l}\text { Investment in education for sustainability } \\
\{3-0\}\end{array}$ & Learning Dimension & $\begin{array}{l}\text { Iizuka et al. (2015); Smith and } \\
\text { Lewis (2011) }\end{array}$ \\
\hline Urban and rural integration $\{3-0\}$ & Organizational Dimension & Iizuka et al. (2015) \\
\hline Urban planning $\{3-1\}$ & Organizational Dimension & Iizuka et al. (2015) \\
\hline Absence of collectivity $\{3-0\}$ & Learning Dimension & $\begin{array}{l}\text { Iizuka et al. (2015) and Smith } \\
\text { and Lewis (2011) }\end{array}$ \\
\hline Absence of adequate access roads $\{2-2\}$ & Organizational Dimension & Iizuka et al. (2015) \\
\hline Absence of qualified professionals $\{2-1\}$ & Learning Dimension & $\begin{array}{l}\text { Iizuka et al. (2015); Smith and } \\
\text { Lewis (2011) }\end{array}$ \\
\hline Absence of the State $\{2-0\}$ & Performance Dimension & $\begin{array}{l}\text { Iizuka et al. (2015); Smith and } \\
\text { Lewis (2011). }\end{array}$ \\
\hline Exhaustion of natural resources $\{2-0\}$ & Performance Dimension & $\begin{array}{l}\text { Iizuka et al. (2015); Smith and } \\
\text { Lewis (2011). }\end{array}$ \\
\hline Lack of social interaction $\{2-0\}$ & Learning Dimension & $\begin{array}{l}\text { Iizuka et al. (2015); Smith and } \\
\text { Lewis (2011). }\end{array}$ \\
\hline Neighbourhood management $\{2-0\}$ & Performance Dimension & $\begin{array}{l}\text { Iizuka et al. (2015); Smith and } \\
\text { Lewis (2011). }\end{array}$ \\
\hline Omission of public authority $\{2-1\}$ & Performance Dimension & $\begin{array}{l}\text { Iizuka et al. (2015); Smith and } \\
\text { Lewis (2011). }\end{array}$ \\
\hline Internal pressure of shareholders. $\{2-0\}$ & Performance Dimension & $\begin{array}{l}\text { Iizuka et al. (2015); Smith and } \\
\text { Lewis (2011). }\end{array}$ \\
\hline $\begin{array}{l}\text { Overlap of responsibilities (neighbourhood } \\
\text { and public authority) }\{2-1\}\end{array}$ & Performance Dimension & $\begin{array}{l}\text { Iizuka et al. (2015) and Smith } \\
\text { and Lewis (2011). }\end{array}$ \\
\hline Technology delayed $\{2-2\}$ & Organizational Dimension & Iizuka et al. (2015) \\
\hline High cost of living in the region $\{1-0\}$ & Organizational Dimension & Iizuka et al. (2015) \\
\hline $\begin{array}{l}\text { Difficulty integrating different social } \\
\text { classes }\{1-0\}\end{array}$ & Learning Dimension & $\begin{array}{l}\text { Iizuka et al. (2015); Smith and } \\
\text { Lewis (2011). }\end{array}$ \\
\hline
\end{tabular}


Table 5 (continued)

\begin{tabular}{|c|c|c|}
\hline Mapped Tensions at Unisul* & $\begin{array}{l}\text { Alignment with Theoretical } \\
\text { Dimensions }\end{array}$ & Author Reference \\
\hline $\begin{array}{l}\text { Exaggerated exploitation of natural } \\
\text { resources }\{1-0\}\end{array}$ & Organizational Dimension & Iizuka et al. (2015) \\
\hline Lack of security $\{1-0\}$ & Performance Dimension & $\begin{array}{l}\text { Iizuka et al. (2015); Smith and } \\
\text { Lewis (2011). }\end{array}$ \\
\hline Legislation of cities $\{1-0\}$ & Performance Dimension & $\begin{array}{l}\text { Iizuka et al. (2015); Smith and } \\
\text { Lewis (2011). }\end{array}$ \\
\hline $\begin{array}{l}\text { Process of urbanisation: residential and } \\
\text { industrial }\{1-0\}\end{array}$ & Performance Dimension & $\begin{array}{l}\text { Iizuka et al. (2015); Smith and } \\
\text { Lewis (2011). }\end{array}$ \\
\hline Land area relief $\{1-1\}$ & Organizational Dimension & Iizuka et al. (2015) \\
\hline Resistance of neighbours $\{1-1\}$ & Learning Dimension & $\begin{array}{l}\text { Iizuka et al. (2015); Smith and } \\
\text { Lewis (2011). }\end{array}$ \\
\hline Environmental constraints $\{1-1\}$ & Organizational Dimension & Iizuka et al. (2015) \\
\hline Segregation of cities $\{1-2\}$ & Performance Dimension & $\begin{array}{l}\text { Iizuka et al. (2015); Smith and } \\
\text { Lewis (2011). }\end{array}$ \\
\hline High property value $\{1-1\}$ & Organizational Dimension & Iizuka et al. (2015) \\
\hline
\end{tabular}

Note. * The number that accompanies the tension was generated by Atlas ti and corresponds to the number of times that this aspect was cited by the investigated

It was noticed that there was a predominance of tensions originating from the organizational dimension and associated with performance. The performance dimension is associated with the plurality of outcomes expected by stakeholders. The existing asymmetry between the expectation of the subjects and the concrete results visualized in the Unisul enterprise has contributed to the fact that the points of tension converge towards the performance dimension. And it challenges managers to find mechanisms to minimize the dilemmas and conflicts that emerge and to align the expectations of the different stakeholders of the Unisul Sustainable enterprise.

In addition, the organizational tension arises from the incorporation of new practices that until then were not common. Technological innovations, new waste management practices, new condominium management behaviors, stimulation of different forms of interaction between the different stakeholders that coexist in the Unisul Sustainable Campus and a futuristic vision for the next 20 years for the venture. Other points of tension evidenced by the study are associated with the value of the image of the organization recognized by society in relation to the intentions of social inclusion; and existing asymmetries between social and economic performance. These aspects are in line with Lyra, Gomes and Jacovine (2009) to infer that better stakeholder management can have a positive impact on the company's sustainability process. In summary, Figure 3 shows the codes that have been repeatedly cited. 


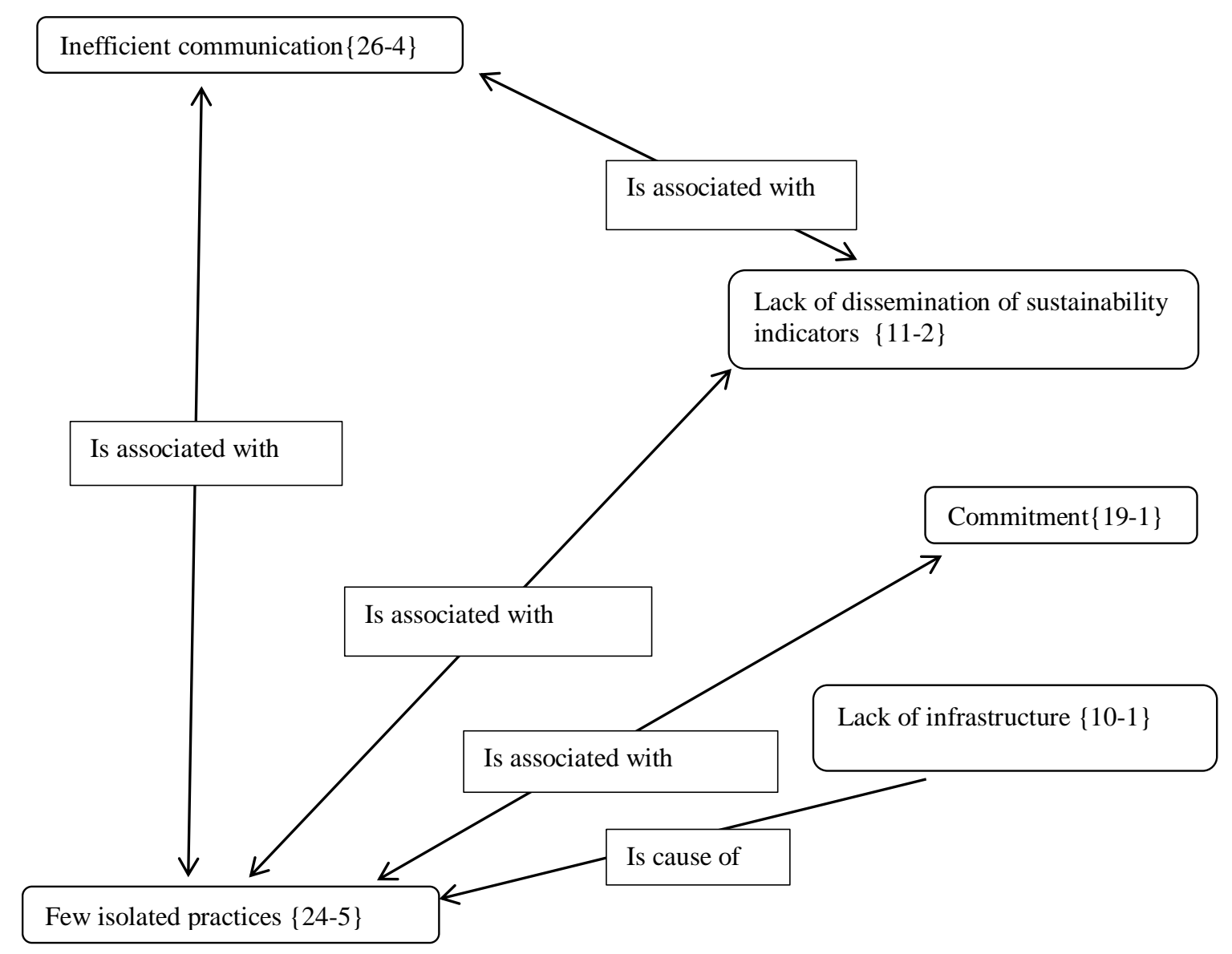

Figure 3. Tensions of Sustainability

Figure 3 shows that the main tensions of sustainability mapped are associated with fragility of the synergy among residents, administrators and the university. The communication process is considered insufficient by the interviewees, and what the entrepreneurs call sustainable, in the respondents' perception, goes back to isolated practices, lacking in synergy and robustness. There is evidence that many interviewees do not cultivate values associated with sustainability, and have superficial knowledge on the subject.

The interviewees feel a lack of greater engagement among public agencies, residents, the university and Pedra Branca frequenters. On the other hand, there are tensions that must exist in this context, such as concern about performance, signalled by the desire of the interviewees to have access to sustainable performance indicators, mention of the cost of adopting sustainability practices, in order to provide broad dissemination; And the manifestation of the desire for collectivity, connectivity and collective coexistence, which indicate the interviewees' concern with the social aspects.

The strategies adopted to manage emerging tensions of sustainability are aligned with those mapped by T. Hahn et al. (2015), that is, strategies of acceptance, opposition, separation and resolution. Therefore, they corroborate the findings of an earlier study carried out by T. Hahn et al. (2015).

Other strategies that can be incorporated to deal with tensions are to create sustainability indicators that align expectations of all relevant stakeholders with sustainable Unisul campus. And adopt management by indicators, with clear communication between all the subjects of the research, use of the technology to create application for real-time communication and management of the expectations of residents, students, shareholders and users of the enterprise. Finally, the results show aspects that have interfaced with Almeida (2007) that choose that the increasing awakening of managers to the need to respect codes of ethics in their this work is related to the equally growing perception among these 
professionals that, in the long term, ethical stance can result in important competitive advantages arising from a positive image projected in the community and increased satisfaction and improvement of the performance of workers.

Although not mentioned in our study, it is possible to infer that another aspect that can contribute to the increase of tensions of sustainability is associated with financial issues. In this sense, GonzálezGaudiano, Meira-Cartea, and Martínez-Fernández (2015), financial issues and the lack of understanding and commitment of top management are seen as the barriers to implementing sustainability in HEIs. Due to these barriers, HEIs focus on short-term decisions for commodification and follow a neoliberal vision and the requirements of the higher education market (González-Gaudiano, Meira-Cartea, \& Martínez-Fernández, 2015) to attract funds and students.

Other obstacles that may provoke tensions and prevent the operationalization of sustainability practices are the lack of human resources for the development of sustainability, information and communication initiatives on sustainability, availability of time, commitment, initiatives, and participation. Including aspects related to the concept of sustainability, lack of instruments for sustainability, resistance to change and organizational structure of HEIs. Financial factors and student attraction seem to be the main future challenges for Portuguese HEIs, a trend already observed in studies carried out in other countries as already pointed out by studies by Elliott and Wright (2013), Wright (2010) and Wright and Horst (2013).

Finally, Brandli, Leal, Frandoloso, Korf, and Daris (2015) considered that sustainability actions in Brazilian universities are mainly the result of isolated projects, and the production of these two issues can explain the fact that the implementation of sustainability in the university routines of these countries does not seem satisfactory or comparable with other European universities (Leal, 2019). In this line, the objective should not be only of development, but of a sustainable society (Aleixo et al., 2018). Such a society is characterized by a culture of peace, and is based on values, attitudes, behaviors and experiences that reinforce non-violence and respect for freedom and fundamental rights of individuals (Aleixo et al., 2018).

\section{Final Remarks}

The main contribution of the study is associated with understanding of the tensions that emerged from the establishment process of Unisul Sustentável - Pedra Branca. It was evident that there was a need to integrate existing sustainable practices, create a communication process that has synergy among all stakeholders, and provide monitoring of sustainable performance indicators. The interviewees are aware of the importance of sustainability, but there is evidence that they possess superficial and disjointed knowledge on the subject.

For the organizational practice, the mapping of the tensions allows to identify points of conflicts, the perception of stakeholders on the origin of the conflict and how they see and deal like these tensions. And this can generate insights to minimize and circumvent them. Managing the stresses related to dynamic balance promotes learning and creativity. This kind of tension also helps companies to be more resilient and flexible, more dynamic decision-making. For the teaching, it shows that the Unisul case is an example of success in terms of sustainability, but there are opportunities to promote improvements. It can be used as a teaching case for sustainable strategies, sustainable architecture and organizational strategies.

At the same time, different strategic options arise to overcome the emerging tensions, namely the strategy of acceptance, opposition, separation and resolution, similar to that mapped out by T. Hahn et al. (2015) in his study. Different stakeholders react in a controversial and contradictory way to the tensions they experience. There are practices of distinguishing extremepositions from tension, maintaining paradoxes, and living with tension. Others are more emphatic, transform the paradox into 
a manageable situation, and seek to create ways and alternatives to coexist harmoniously with the emerging tensions of sustainability.

Similar to the evidence from studies by Adams et al. (2018), Aleixo et al. (2018), Bizerril et al. (2018), Hermes and Romanoczy (2018), in Brazil, it is necessary to invest in education for sustainability. The teaching of sustainability, which allows the creation of citizens who hold values for sustainability, is fundamental to create a favorable culture for the progress of sustainability. Knowing in depth the specificities of sustainability and how to operationalize them is the first question so that it is possible to move towards a sustainable society. Adams et al. (2018) stress that if an organization has an appropriate culture of sustainability, its members and stakeholders will engage in a sustainable relationship with it and translate it to the organizational level.

The main limitation of the research was associated with the difficulty of accessing secondary data to perform triangulation of the research results. It is recommended for future studies to map the indicators that are possibly being monitored and to create a checklist of indicators relevant to sustainable enterprises,plus a proposal on how to implement them, and create monitoring and management strategies based on sustainable indicators. Another suggestion of the study is to map how universities adopting sustainable practices are teaching their students to create a culture for sustainability. Likewise, how to raise awareness so that attitude and sustainable behavior become routine in higher education institutions. Analyze the sustainable campus from the point of view of the theory of ecological modernization. And lastly, introduce a curricular component of literacy for sustainability, to introduce the necessary premises for the formation of a culture for sustainability.

\section{References}

Adams, R., Martin, S., \& Boom, K. (2018). University culture and sustainability: Designing and implementing an enabling framework. Journal of Cleaner Production, 171, 434-445. http://doi.org/10.1016/j.jclepro.2017.10.032

Aleixo, A. M., Leal, S., \& Azeiteiro, U. M. (2018). Conceptualization of sustainable higher education institutions, roles, barriers, and challenges for sustainability: An exploratory study in Portugal. Journal of Cleaner Production, 172, 1664-1673. http://doi.org/10.1016/j.jclepro.2016.11.010

Almeida, F. J. R. (2007). Ética e desempenho social das organizações: um modelo teórico de análise dos fatores culturais e contextuais. Revista de Administração Contemporânea, 11(3), 105-125. Recuperado de http://www.scielo.br/pdf/rac/v11n3/a06v11n3.pdf. http://doi.org/10.1590/S141565552007000300006

Bardin, L. (2011) Análise de conteúdo. São Paulo: Edições 70.

Berger, I. E., Cunningham, P., \& Drumwright, M. E. (2007). Mainstreaming corporate social responsibility: Developing markets for virtue. California Management Review, 49(4), 132-157. http://doi.org/10.2307/41166409

Bizerril, M., Rosa, M. J., Carvalho, T., \& Pedrosa, J. (2018). Sustainability in higher education: A review of contributions from Portuguese Speaking Countries. Journal of Cleaner Production, 171, 600612. http://doi.org/10.1016/j.jclepro.2017.10.048

Brandli, L. L., Leal, W., Filho, Frandoloso, M. A. L., Korf, E. P., \& Daris, D. (2015). The environmental sustainability of Brazilian Universities: Barriers and pre-conditions. In W. Leal Filho, U. M. Azeiteiro, S. Caieiro, \& F. Alves (Eds), Integrating sustainability thinking in science and engineering curricula (pp. 63-74). New York: Springer. 
Chuvieco, E., Burgui-Burgui, M., Silva, E. V. da, Hussein, K., \& Alkaabi, K. (2018). Factors affecting environmental sustainability habits of university students: Intercomparison analysis in three countries (Spain, Brazil and UAE). Journal of Cleaner Production, 198, 1372-1380. http://doi.org/10.1016/j.jclepro.2018.07.121

Cidade Criativa Pedra Branca. (2016). Um pouco de história. Recuperado de http://www.cidadepedrabranca.com.br/um-pouco-de-historia

Csutora, M. (2011). From eco-efficiency to eco-effectiveness? The policy-performance paradox. Society and Economy, 33(1), 161-181. http://doi.org/10.1556/SocEc.33.2011.1.12

Dentchev, N. A. (2004). Corporate social performance as a business strategy. Journal of Business Ethics, 55(4), 397-412. https://doi.org/10.1007/s10551-004-1348-5

Elkington, J. (1997). Cannibals with forks: The triple bottom line of 21st century business. Gabriola Island, British Columbia: New Society.

Elliott, H., \& Wright, T. (2013). Barriers to sustainable universities and ways forward: A Canadian students' perspective. Proceedings of the 3rd World Sustainability Forum, Retrieved from https://www.researchgate.net/publication/269203082_Barriers_to_Sustainable_Universities_and _Ways_Forward_A_Canadian_students_Perspective/download

González-Gaudiano, E. J., Meira-Cartea, P. Á, \& Martínez-Fernández, C. N. (2015). Sustentabilidad y Universidad: Retos, ritos y posibles rutas. Revista de la Educación Superior, 44(175), 69-93.

Haffar, M., \& Searcy, C. (2017). Classification of trade-offs encountered in the practice of corporate sustainability. Journal of Business Ethics, 140(3), 495-522. https://doi.org/10.1007/s10551-0152678-1

Hahn, R., (2012). Standardizing social responsibility? New perspectives on guidance documents and management system standards for sustainable development. Transactions on Engineering Management, 59(4), 717-727. https://doi.org/10.1109/TEM.2012.2183639

Hahn, T. (2015). Reciprocal stakeholder behavior: A motive-based approach to the implementation of normative stakeholder demands. Business \& Society, 54(1), 9-51. https://doi.org/10.1177/0007650312439029

Hahn, T., Figge, F., Pinkse, J., \& Preuss, L. (2010). Editorial trade-offs in corporate sustainability: You can't have your cake and eat it. Business Strategy and the Environment Bus. Strat. Env. 19, 217 229. https://doi.org/10.1002/bse.674

Hahn, T., Pinkse, J., Preuss, L., \& Figge, F. (2015). Tensions in corporate sustainability: Towards an integrative framework. Journal of Business Ethics, 127(2), 297-316. https://doi.org/10.1007/s10551-014-2047-5

Hahn, T., Preuss, L., Pinkse, J., \& Figge, F. (2014). Cognitive frames in corporate sustainability: Managerial sensemanking with paradoxical and business case frames. Academy of Management Review, 39(4),463-487. https://doi.org/10.5465/amr.2012.0341

Hermes, J., \& Rimanoczy, I. (2018). Deep learning for sustainability mindset. The International Journal of Management Education, 16(3), 460-467. https://doi.org/10.1016/j.ijme.2018.08.001

Husted, B. W., \& Salazar, J. de Jesus (2006). Taking Friedman seriously: Maximizing profits and social performance. Journal of Management Studies, 43(1), 75-91. https://doi.org/10.1111/j.14676486.2006.00583.x 
Iizuka, E., Varela, C., \& Larroudé, E. (2015). Social business dilemmas in Brazil: Rede Asta case. Revista de Administração de Empresas, 55(4), 385-396. http://doi.org/10.1590/S0034759020150403

Leal, W., Filho (Ed.). (2009). Sustainability at universities-Opportunities, challenges and trends. Frankfurt: Peter Lang.

Lozano, R. (2011). The state of sustainability reporting in universities. International Journal of Sustainability in Higher Education, 12(1), 67-78. https://doi.org/10.1108/14676371111098311

Lyra, M. G., Gomes, R. C., \& Jacovine, L. A. G. (2009). O papel dos stakeholders na sustentabilidade da empresa: Contribuições para construção de um modelo de análise [Edição Especial]. Revista de Administração Contemporânea, 13, 39-52. Recuperado de http://www.scielo.br/pdf/rac/v13nspe/a04v13nspe. $\quad$ http://doi.org/10.1590/S141565552009000500004

Marques, J. P. C., Caraça, J. M. G., \& Diz, H. (2010). Do business incubators function as a transfer technology mechanism from university to industry? Evidence from Portugal. The Open Business Journal, 3(1), 15-29. http://doi.org/10.2174/1874915101003010015

Nogueira, M. D. P. (2013). O fórum de pró-reitores de extensão das universidades públicas brasileiras: Um ator social em construção. Interfaces - Revista de Extensão, 1(1), 35-47

Schwartz, M. S., \& Carroll, A. B. (2008). Integrating and unifying competing and complementary frameworks. The search for a Common core in the business and society field. Business and Society, 47(2), 148-186. http://doi.org/10.1177/0007650306297942

Segalàs, J., Mulder, K. F., \& Ferrer-Balas, D. (2012). What do EESD "experts" think sustainability is? Which pedagogy is suitable to learn it? Results from interviews and Cmaps analysis gathered at EESD 2008. International Journal of Sustainability in Higher Education, 13(3), 293-304. https://doi.org/10.1108/14676371211242599

Smith, W. K., \& Lewis, M. W. (2011). Toward a theory of paradox: A dynamic equilibrium model of organizing. Academy of Management Review, 36(2), 381-403. http://doi.org/10.5465/AMR.2011.59330958

Soini, K., Jurgilevich, A., Pietikäinen, J., \& Korhonen-Kurki, K. (2018). Universities responding to the call for sustainability: A typology of sustainability centres. Journal of Cleaner Production, 170, 1423-1432. http://doi.org/10.1016/j.jclepro.2017.08.228

Vieira, K. R. O., Battistelle, R. A. G., Bezerra, B. S., Castro, R. de, Jabbour, C. J. C., \& Deus, R. M. (2018). An exploratory study of environmental practices in two Brazilian higher education institutions. Journal of Cleaner Production, 187, 940-949. https://doi.org/10.1016/j.jclepro.2018.03.260

Universidade do Sul de Santa Catarina. (n.d). Unidade Pedra Branca. Recuperado de http://www.unisul.br/wps/portal/home/conheca-a-unisul/a-universidade/campus-grandeflorianopolis/unidade-pedra-branca

Wagner, M. (2015). The link of environmental and economic performance: Drivers and limitations of sustainability integration. Journal of Business Research, 68(6), 1306-1317. https://doi.org/10.1016/j.jbusres.2014.11.051

Wright, T. (2010). University presidents' conceptualizations of sustainability in higher education. International Journal of Sustainability in Higher Education, 11(1), 61-73. http://doi.org/10.1108/14676371011070057 
Wright, T., \& Horst, N. (2013). Exploring the ambiguity: What faculty leaders really think of sustainability in higher education. International Journal of Sustainability in Higher Education, 14(2), 209-227. http://doi.org/10.1108/14676371311312905

Zutshi, A., \& Creed, D. A. (2018). Declaring talloires: Profile of sustainability communications in Australian signatory universities. Journal of Cleaner Production, 187, 687-698. http://doi.org/10.1016/j.jclepro.2018.03.225

\section{Authors}

Simone Sehnem

Av. Nereu Ramos, 3777-D, 89813-000, Chapecó, SC, Brasil.

E-mail address: simonesehnem_adm@yahoo.com.br

Graciella Martignago

Rua Adolfo Melo, 34, Centro, 88015-090, Florianópolis, SC, Brasil

E-mail address: graciellamartignago@gmail.com

Susana Carla Farias Pereira

Rua Itapeva, 432, 01332-000, São Paulo, SP, Brasil

E-mail address: susana.pereira@fgv.br

Charbel Jose Chiappetta Jabbour

FK9 4LA, Stirling, Scotland, UK

E-mail address: cjcjabbour@gmail.com

\section{Contributions}

1st author: Definition of research, theoretical and methodological development, writing and final revision.

2nd author: Definition of research, theoretical and methodological development, writing and final revision.

3rd author: Definition of research, theoretical and methodological development, writing and final revision.

4th author: Definition of research, theoretical and methodological development, writing and final revision.

\section{Funding}

The authors reported that there is no financial support for the research in this article.

\section{Conflict of Interest}

The authors have stated that there is no conflict of interest.

\section{Plagiarism Check}

The RAC maintains the practice of submitting all documents approved for publication to the plagiarism check, using specific tools, e.g.: iThenticate. 